\title{
Sunitinib uptake inhibits platelet function in cancer patients
}

Citation for published version (APA):

Sabrkhany, S., Griffioen, A. W., Pineda, S., Sanders, L., Mattheij, N., van Geffen, A., Aarts, M. J., Heemskerk, J. W. M., Oude Egbrink, M., \& Kuijpers, M. J. E. (2016). Sunitinib uptake inhibits platelet function in cancer patients. European Journal of Cancer, 66, 47-54.

https://doi.org/10.1016/j.ejca.2016.07.016

Document status and date:

Published: 01/10/2016

DOI:

10.1016/j.ejca.2016.07.016

Document Version:

Publisher's PDF, also known as Version of record

Document license:

Taverne

Please check the document version of this publication:

- A submitted manuscript is the version of the article upon submission and before peer-review. There can be important differences between the submitted version and the official published version of record.

People interested in the research are advised to contact the author for the final version of the publication, or visit the DOI to the publisher's website.

- The final author version and the galley proof are versions of the publication after peer review.

- The final published version features the final layout of the paper including the volume, issue and page numbers.

Link to publication

\footnotetext{
General rights rights.

- You may freely distribute the URL identifying the publication in the public portal. please follow below link for the End User Agreement:

www.umlib.nl/taverne-license

Take down policy

If you believe that this document breaches copyright please contact us at:

repository@maastrichtuniversity.nl

providing details and we will investigate your claim.
}

Copyright and moral rights for the publications made accessible in the public portal are retained by the authors and/or other copyright owners and it is a condition of accessing publications that users recognise and abide by the legal requirements associated with these

- Users may download and print one copy of any publication from the public portal for the purpose of private study or research.

- You may not further distribute the material or use it for any profit-making activity or commercial gain

If the publication is distributed under the terms of Article $25 \mathrm{fa}$ of the Dutch Copyright Act, indicated by the "Taverne" license above, 


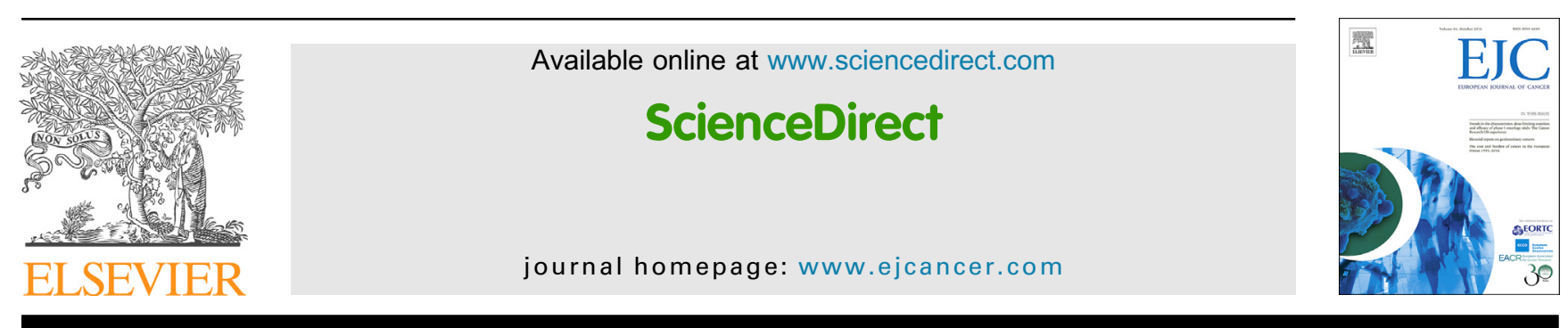

Original Research

\title{
Sunitinib uptake inhibits platelet function in cancer patients
}

\author{
Siamack Sabrkhany ${ }^{\mathrm{a}}$, Arjan W. Griffioen ${ }^{\mathrm{b}}$, Sharo Pineda ${ }^{\mathrm{a}}$, \\ Linda Sanders ${ }^{a}$, Nadine Mattheij ${ }^{c}$, Johanna P. van Geffen ${ }^{c}$, \\ Maureen J. Aarts ${ }^{\mathrm{d}}$, Johan W.M. Heemskerk ${ }^{\mathrm{c}}$, \\ Mirjam G.A. oude Egbrink ${ }^{a}$, Marijke J.E. Kuijpers ${ }^{c, *}$ \\ ${ }^{a}$ Cardiovascular Research Institute Maastricht, Department of Physiology, Maastricht University, Maastricht, The \\ Netherlands \\ b Angiogenesis Laboratory, Department of Medical Oncology, VU Medical Center, Amsterdam, The Netherlands \\ ${ }^{\mathrm{c}}$ Cardiovascular Research Institute Maastricht, Department of Biochemistry, Maastricht University, Maastricht, The \\ Netherlands \\ ${ }^{\mathrm{d}}$ Department of Medical Oncology, Maastricht University Medical Centre, Maastricht, The Netherlands
}

Received 17 March 2016; received in revised form 9 June 2016; accepted 5 July 2016

Available online 12 August 2016

\section{KEYWORDS}

Platelet activation;

Cancer;

Platelet signalling;

Thrombus;

Sunitinib;

Angiogenesis
Abstract Background: Sunitinib is an oral tyrosine kinase inhibitor used for cancer treatment. Patients treated with sunitinib are at higher bleeding risk. As tyrosine kinases are essential for platelet signalling, the effects of sunitinib on platelet function in vitro and in cancer patients on treatment were investigated.

Patients and methods: Blood samples were collected from eight healthy volunteers and eight patients diagnosed with metastatic renal cell cancer (RCC) before and 2 weeks on treatment with sunitinib. Platelets from 15 additional healthy individuals were preincubated with sunitinib or vehicle to perform in vitro experiments. Immunofluorescence imaging, western blotting, light transmission aggregometry, whole blood perfusion over collagen, flow cytometry and ELISA were performed.

Results: Confocal microscopy indicated that platelets sequester sunitinib in vitro and in patients. In platelets from healthy controls, tyrosine phosphorylation was inhibited by sunitinib. Also, sunitinib dose dependently reduced collagen- and ADP-induced aggregation, collagendependent thrombus formation and collagen-induced secretion of platelet-derived growth factor and $\beta$-thromboglobulin. In blood from RCC patients before treatment, thrombus formation and procoagulant activity under flow were $47 \%$ and $80 \%$ higher than in healthy controls.

* Corresponding author: Department Biochemistry (CARIM), Maastricht University, PO Box 616, 6200 MD Maastricht, The Netherlands. Fax: +31433884159.

E-mail address: Marijke.Kuijpers@maastrichtuniversity.nl (M.J.E. Kuijpers). 
After $14 \mathrm{~d}$ of sunitinib treatment, platelet count was moderately, but significantly decreased (from 243 to $144 \times 10^{9} / 1$ ). At the same time, collagen-induced platelet aggregation as well as thrombus formation and phosphatidylserine exposure under flow were significantly reduced (by $45 \%, 16 \%$ and $61 \%$, respectively).

Conclusions: Sunitinib uptake by platelets inhibits collagen receptor-induced aggregation and thrombus formation via reduction of protein tyrosine phosphorylation and $\alpha$-granule secretion. This dysfunction may contribute to the higher bleeding tendency observed in sunitinib-treated patients.

(c) 2016 Elsevier Ltd. All rights reserved.

\section{Introduction}

Inhibition of protein tyrosine kinases has shown considerable anticancer activity in patients with malignancies [1]. The multitarget tyrosine kinase inhibitor (TKI) sunitinib has been approved for the treatment of advanced renal cell cancer (RCC) and for imatinibresistant gastrointestinal and pancreatic neuroendocrine tumours [2]. The effect of sunitinib in the management of several other malignancies is currently being explored in several trials (ClinicalTrials.gov Identifiers: NCT02074878, NCT01396148, NCT02058901 and NCT00753727).

Although treatment with sunitinib has shown anticancer effects and improves progression-free survival, patients treated with this TKI may also encounter bleeding. Overall, bleeding occurs in approximately $19 \%$ of sunitinib-treated patients; about $3 \%$ of the bleeding incidents are life threatening [3]. The mechanism underlying this higher bleeding diathesis in patients treated with sunitinib is still poorly understood. Haemostasis upon vessel wall injury is an intricate process in which platelets play a major role; it involves activation of platelets by multiple exogenous and autocrine agonists and their receptors [4]. Exposed extracellular matrix proteins, including collagen and von Willebrand Factor (vWF), first mediate platelet adhesion and activation, as a prerequisite for ensuing aggregation and thrombus formation. A subpopulation of activated platelets exposes phosphatidylserine which promotes thrombin generation and fibrin formation [5,6]. Platelets contain multiple active protein tyrosine kinases [4] that are essential for platelet functioning in haemostasis. Moreover, platelets also play an important role in tumour angiogenesis and cancer progression [7]. The role of platelets in sunitinib-induced toxicity has not been explored.

The current study examined the hypothesis that sunitinib treatment of cancer patients impairs platelet haemostatic function, explaining the higher occurrence of bleeding in patients undergoing this treatment. We investigated the effects of sunitinib on platelet activation, aggregation and thrombus formation both in vitro and in patients with RCC.

\section{Patients and methods}

\subsection{Patients}

The study was approved by the medical ethics committee from Maastricht University Medical Centre+ (MUMC+, The Netherlands). Informed consent was obtained from all participants in accordance with the declaration of Helsinki. At the department of Medical Oncology of MUMC+, blood samples were obtained from eight patients diagnosed with metastatic RCC and eight healthy donors who were similar in age and gender to the RCC patients. The patients included were treated with sunitinib (Sutent $^{\circledR}$, Pfizer, NYC, USA) as a single agent. Subjects who used anticoagulants or platelet inhibitory drugs or received chemotherapy were excluded. One blood sample was collected from the healthy donors; in the patient group, blood was sampled two times: $1 \mathrm{~d}$ before and $14 \mathrm{~d}$ after starting sunitinib treatment, i.e., within the first cycle of treatment. Blood $(10 \mathrm{ml})$ was collected from the antecubital vein in $3.2 \%$ sodium citrate, and washed platelets were prepared as described [8].

For all experiments in which the effects of sunitinib on platelet functioning were measured in vitro, blood samples from 15 additional healthy volunteers were used. Before measurements, washed platelets or whole blood from these healthy donors were preincubated with sunitinib $(3.33,10$ or $30 \mu \mathrm{M})$ or vehicle for $10 \mathrm{~min}$ at $37{ }^{\circ} \mathrm{C}$. Detailed information regarding used materials is described in Supplementary materials.

\subsection{Methods}

Immunofluorescence imaging by confocal microscopy, western blotting, light transmission aggregometry, whole blood perfusion over collagen, flow cytometry and ELISA were performed as described in Supplementary methods.

\subsection{Statistical analysis}

Data were checked for Gaussian distribution using the Kolmogorov-Smirnov Normality test. Normally 
distributed data are presented as means \pm SEM; data that are not normally distributed are presented as median \pm interquartile ranges. GraphPad Prism 5.0 software was used for statistical analyses. Paired data sets were compared using the Wilcoxon matched pairs test, while unpaired samples were compared using the Mann-Whitney U test. A $P$-value less than 0.05 was considered statistically significant.

\section{Results}

\subsection{Sunitinib is sequestered by platelets and inhibits collagen-induced protein tyrosine phosphorylation}

Visualisation by confocal microscopy of washed platelets from healthy individuals that were treated with $10 \mu \mathrm{M}$ sunitinib showed that platelets accumulate sunitinib and sequester this fluorescent compound in granules (Fig. 1A). This uptake of sunitinib from the environment was observed within minutes after exposure. Platelets contain several tyrosine kinases implicated in platelet functioning, mostly acting in the collagen-induced signalling pathway [4]. Western blotting was used to investigate whether sunitinib affects tyrosine phosphorylation of platelet proteins upon collagen stimulation. Preincubation of washed platelets with $10 \mu \mathrm{M}$ sunitinib strongly reduced the tyrosine phosphorylation of multiple proteins induced by collagen (Fig. 1B).

\subsection{Sunitinib inhibits collagen- and ADP-induced platelet aggregation, thrombus formation and secretion in vitro}

To investigate the effect of sunitinib on platelet functioning, we first measured platelet aggregation induced by different physiological agonists. Washed platelets from healthy volunteers were treated for $10 \mathrm{~min}$ with $10 \mu \mathrm{M}$ sunitinib. Platelet aggregation was induced with thrombin, TRAP-6 (thrombin receptor activating peptide 6, activating PAR-1), collagen, U46619 (thromboxane $\mathrm{A}_{2}$ analog), ADP and arachidonic acid. Only in response to collagen and ADP, sunitinib inhibited platelet aggregation (Supplementary Fig. 1). This inhibiting effect of sunitinib on platelet aggregation appeared to be dose dependent. While the maximal aggregation response to either agonist was already significantly inhibited by $10 \mu \mathrm{M}$ sunitinib, this response was almost completely prevented by $30 \mu \mathrm{M}$ (Fig. 2A,B).

Subsequently, we determined the effect of sunitinib on collagen-induced thrombus formation at high (arterial) wall shear rates. In whole blood perfusion experiments, preincubation of blood with $10 \mu \mathrm{M}$ sunitinib slightly but significantly reduced thrombus formation on collagen by $14 \%$ (Fig. 2C). With a higher sunitinib dose
A

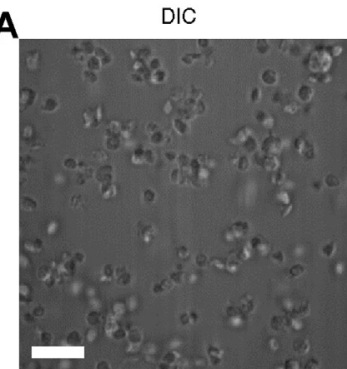

B

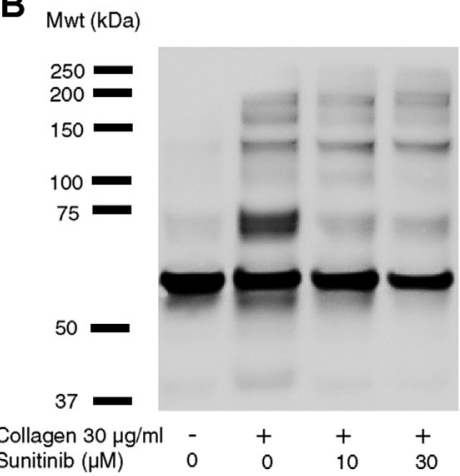

sunitinib
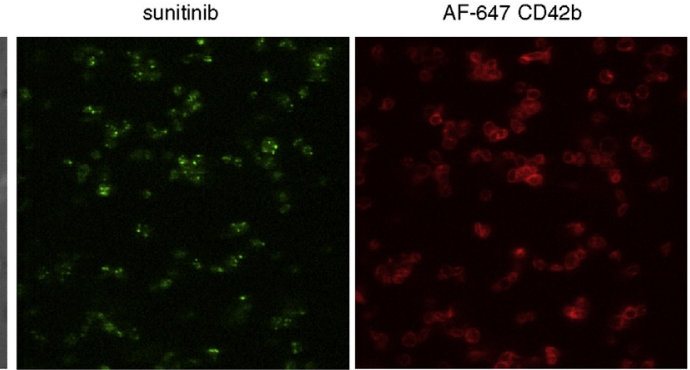

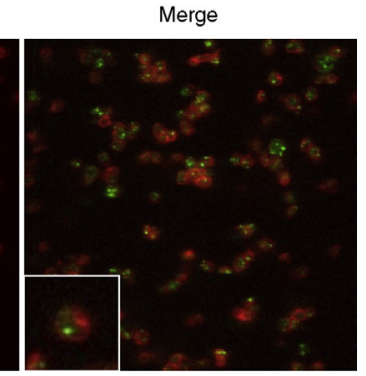

Merge 
A

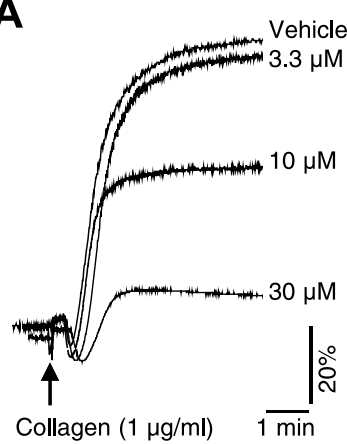

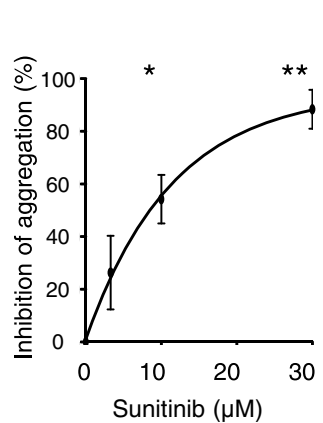
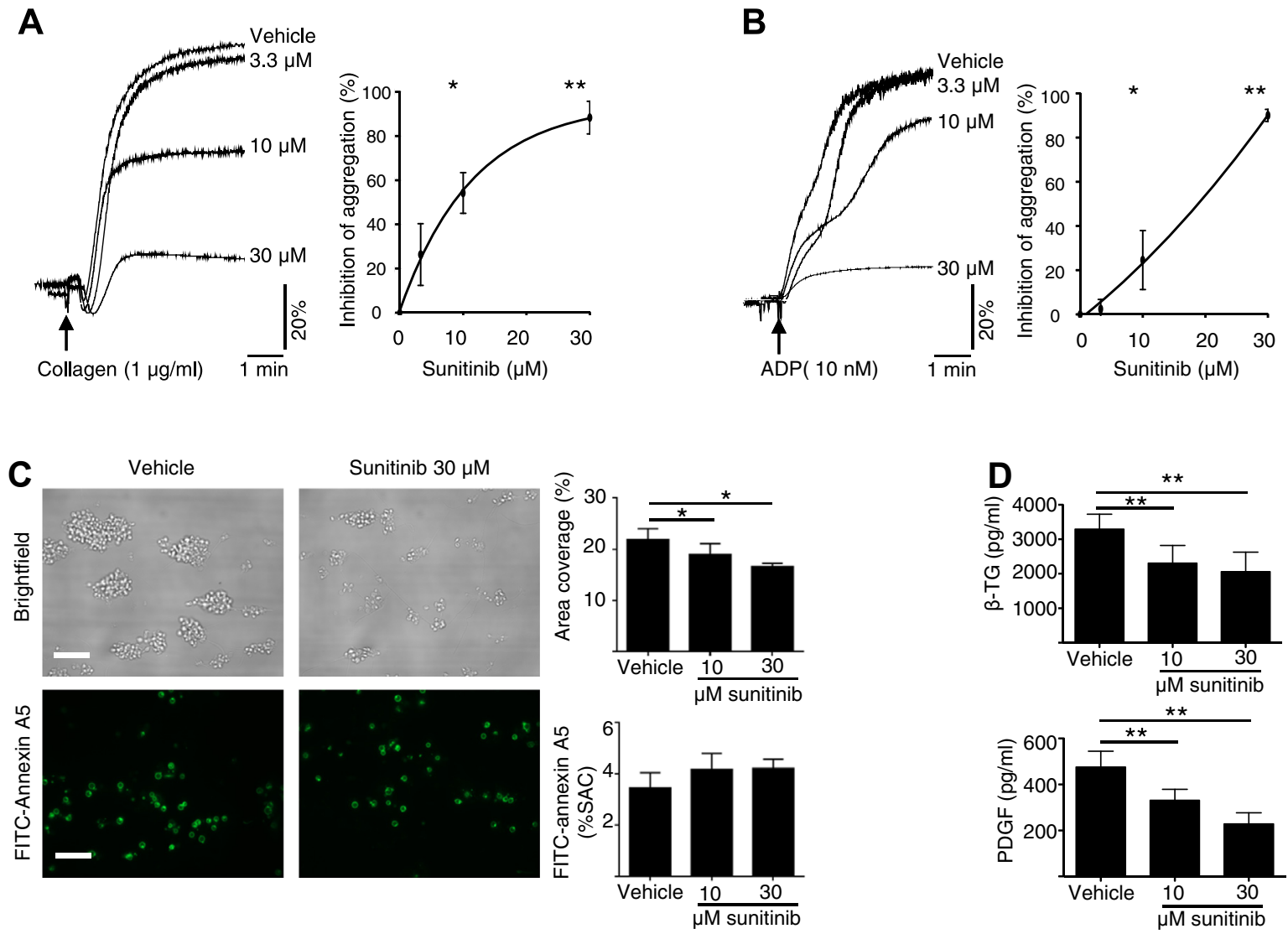

Fig. 2. Sunitinib inhibits collagen and ADP-induced platelet aggregation, thrombus formation and secretion in vitro. Whole blood or washed platelets $\left(250 \times 10^{9} / 1\right)$ from healthy donors were incubated with $3.3,10$ or $30 \mu \mathrm{M}$ sunitinib or vehicle $(0.1 \% \mathrm{DMSO})$ for $10 \mathrm{~min}$. (A and $\mathrm{B})$ : Representative aggregation curves and dose-response graphs $(\mathrm{n}=8)$ of inhibition of aggregation. Arrow indicates addition of agonist. Aggregation of washed platelets was stimulated with $1 \mu \mathrm{g} / \mathrm{ml}$ collagen (A) or $10 \mathrm{nM}$ Me-S-ADP (B). (C) Whole blood was perfused over a collagen surface at $1000 \mathrm{~s}^{-1}$ for $5 \mathrm{~min}$, followed by buffer perfusion supplemented with FITC-annexin A5. Microscopy images show representative brightfield and fluorescence images $($ Bar $=20 \mu \mathrm{m})$. Histograms indicate quantification of surface area coverage (SAC) by thrombi $(n=5)$ and phosphatidylserine-exposing platelets $(n=4)$. (D) Washed platelets were stimulated by collagen $(1 \mu \mathrm{g} / \mathrm{ml})$, and releasates were collected; concentrations of $\beta$-thromboglobulin $(\beta-\mathrm{TG})$ and PDGF were determined by ELISA ( $=7)$. All data are expressed as means $\pm \mathrm{SEM},{ }^{*} P<0.05$ and ${ }^{* *} P<0.01$. PDGF $=$ platelet-derived growth factor; ELISA $=$ enzyme-linked immunosorbent assay; ADP = adenosine diphosphate; DMSO = dimethyl sulfoxide; $\mathrm{SEM}=$ standard error of the mean; FITC $=$ fluorescein isothiocyanate.

$(30 \mu \mathrm{M})$, thrombus formation was reduced further (by $24 \%$ as compared to vehicle, Fig. 2C). Treatment of whole blood with sunitinib did not affect exposure of phosphatidylserine (Fig. 2C).

To explore the effect of sunitinib on platelet secretion, washed platelets were treated with 10 or $30 \mu \mathrm{M}$ sunitinib and activated with $1 \mu \mathrm{g} / \mathrm{ml}$ collagen. Secretion of both $\beta$-thromboglobulin ( $\beta$-TG) and platelet-derived growth factor (PDGF) was significantly reduced by both concentrations of sunitinib (Fig. 2D).

\subsection{Treatment with sunitinib inhibits collagen-induced platelet function in RCC patients}

To investigate the clinical significance of inhibition of platelet functioning by sunitinib, eight patients diagnosed with metastatic RCC and eligible for sunitinib treatment (Table 1) were examined. These were compared with eight healthy individuals of comparable age and gender. The patients had a mean age of 67 (range: 51-86) years and comprised six females. The control subjects had a mean age of $61(53-73)$ years, of which five were female. Blood samples were collected from patients $1 \mathrm{~d}$ before and $14 \mathrm{~d}$ after the start of sunitinib treatment. A single blood sample was collected from the control donors. Median platelet count of RCC patients was 243 (range: $200-526$ ) $\times 10^{9} / 1$ before the start of sunitinib treatment, which was not significantly different from healthy controls $\left(212 \times 10^{9} / 1\right.$; range: 167-300). Fourteen days of sunitinib treatment were accompanied by a significant decrease in platelet count to $144 \times 10^{9} / 1$ (range: $66-563, P<0.05$ ). Bleeding events were reported from the start of sunitinib treatment until 2 weeks after the second blood sample (i.e. 
Table 1

Characteristics of patients treated with sunitinib.

\begin{tabular}{|c|c|c|c|c|c|c|}
\hline $\begin{array}{l}\text { Patient } \\
\text { no. }\end{array}$ & Gender & $\begin{array}{l}\text { Age } \\
\text { (year) }\end{array}$ & $\begin{array}{l}\text { Drug } \\
\text { treatment } \\
(\mathrm{mg} / \mathrm{d})\end{array}$ & $\begin{array}{l}\text { Platelet } \\
\text { count } \\
\text { day } 0 \\
\left(\times 10^{9} / 1\right)\end{array}$ & $\begin{array}{l}\text { Platelet } \\
\text { count } \\
\text { day } 14 \\
\left(\times 10^{9} / 1\right)\end{array}$ & Bleeding $^{\mathrm{a}}$ \\
\hline 1 & Female & 69 & 50 & 234 & 124 & Epistaxis \\
\hline 2 & Female & 86 & 50 & 296 & 66 & No \\
\hline 3 & Female & 57 & 50 & 213 & 182 & No \\
\hline 4 & Male & 84 & 50 & 200 & 128 & $\begin{array}{l}\text { Epistaxis/GI } \\
\text { bleeding }\end{array}$ \\
\hline 5 & Male & 51 & 50 & 253 & 104 & No \\
\hline 6 & Female & 62 & 25 & 285 & 268 & No \\
\hline 7 & Female & 72 & 50 & 526 & 563 & Epistaxis \\
\hline 8 & Female & 58 & 50 & 230 & 160 & Epistaxis \\
\hline
\end{tabular}

$\mathrm{GI}=$ gastrointestinal.

${ }^{\text {a }}$ Bleeding events were reported during the first 4 weeks (= first cycle) of sunitinib treatment.

during the four weeks [ = first cycle] of sunitinib treatment). Bleeding complications were observed in four patients. Three patients developed mild epistaxis, while one patient presented with gastrointestinal bleeding requiring blood transfusion.

We investigated the effects of sunitinib treatment of patients on the functioning of their platelets. Confocal microscopy of platelets from RCC patients treated with sunitinib indicated significant sequestration of this fluorescent compound into the cytoplasm and granular structures (Fig. 3A). This observation confirmed that, also in patients, platelets take up sunitinib. Before the start of treatment, collagen- and ADP-induced aggregation of platelets from RCC patients did not differ from control (Fig. 3B,C). However, after $14 \mathrm{~d}$ of sunitinib treatment, the platelet response to collagen was significantly reduced by $45 \%$ in the patient group (Fig. 3B). Aggregation of patient platelets in response to ADP was not influenced by sunitinib treatment (Fig. 3C).

The aggregation data were confirmed by flow cytometric measurements of platelet integrin $\alpha \operatorname{IIb} \beta 3$ activation and $\alpha$-granule secretion (P-selectin expression). No differences in platelet activation were found between healthy subjects and patients before the start of treatment. After 2 weeks on sunitinib treatment, the patients' platelets showed a diminished response with convulxin, an agonist for the collagen receptor Glycoprotein VI (GPVI) (Supplementary Fig. 2). Platelet activation responses to ADP or thrombin were not significantly influenced.

In whole blood perfusion experiments over a collagen surface, blood from healthy donors demonstrated reproducible platelet deposition and subsequent thrombus formation (Fig. 3D: median surface area coverage $28 \%, \mathrm{n}=8$ ). Before treatment, perfusion of patient blood resulted in an increased accumulation of platelets on the collagen surface and the formation of larger packed thrombi when compared to healthy controls (Fig. 3D). Quantification of the area covered by platelets revealed a $47 \%$ increase in thrombus formation in patients compared to controls of similar age and gender (Fig. 3D). Two weeks after the start of sunitinib treatment, thrombus formation was significantly reduced by $16 \%$ (Fig. 3D).

To detect phosphatidylserine-exposing platelets, we poststained with fluorescently labelled annexin A5 and observed ample procoagulant platelets on the collagen with blood from healthy subjects (Fig. 3D). In RCC patients before treatment, the amount of phosphatidylserine-exposing platelets was significantly increased by $80 \%$ (Fig. 3D). Two weeks of sunitinib treatment significantly diminished the area covered by platelets exposing phosphatidylserine to the healthy control level (Fig. 3D).

\section{Discussion}

The present study shows that the multi-TKI sunitinib is taken up by platelets and inhibits collagen receptorinduced integrin activation, secretion, aggregation and thrombus formation. Protein tyrosine kinases are abundantly expressed in platelets and play important roles in platelet activation and haemostasis [9]. It has been shown that sunitinib also affects tyrosine kinases that are expressed in platelets [10]. This may explain that sunitinib treatment was accompanied by bleeding episodes in four of eight investigated cancer patients (Table 1 ), which is in agreement with reports on the use of several other non-selective TKIs in cancer therapy $[3,11,12]$. As no correlation existed between absolute platelet count and the occurrence of bleeding (Table 1) and the reduction in platelet count was only moderate in RCC patients on treatment with sunitinib, it is unlikely that the decrease in platelet count alone leads to bleeding. The present results also demonstrate that sunitinib reduces platelet functioning. Hence, this combination of antiplatelet effects (i.e. both on platelet count and functioning) may contribute to the higher bleeding risk observed in patients treated with sunitinib. In addition, endothelial dysfunction and increased capillary leakage as induced by treatment with sunitinib or other angiogenesis inhibitors [13] may also play a role in the increased bleeding tendency. Paradoxically, interfering with the integrity of the endothelial cells can also shift the haemostatic balance in favour of thrombosis; treatment with sunitinib and other TKIs have also been associated with an increase in arterial thromboembolic events in RCC patients [13,14].

Sunitinib sequestration has been reported in lysosomes of tumour cells and endothelial cells [15]. Because platelets are also known to incorporate substances from plasma, like angiogenesis regulators [16] and antiangiogenic medication [17], it was hypothesised that platelets take up sunitinib as well. Confocal microscopy 
A

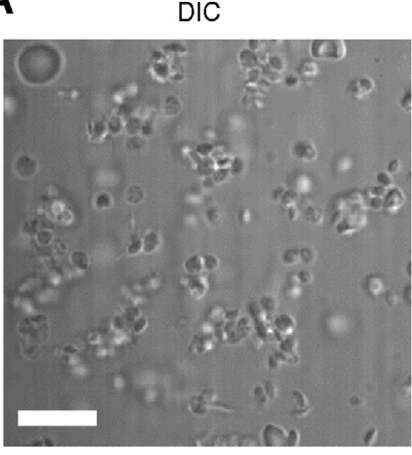

B

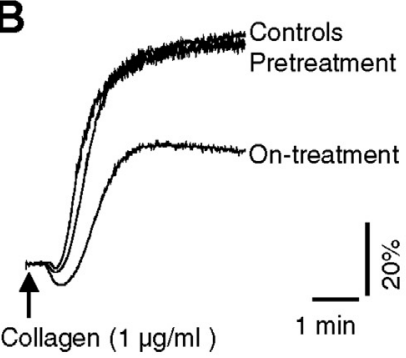

sunitinib
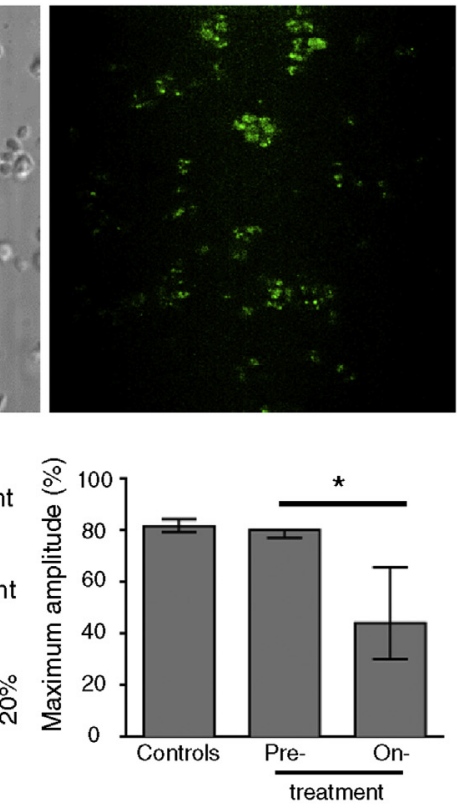

AF-647 CD42b

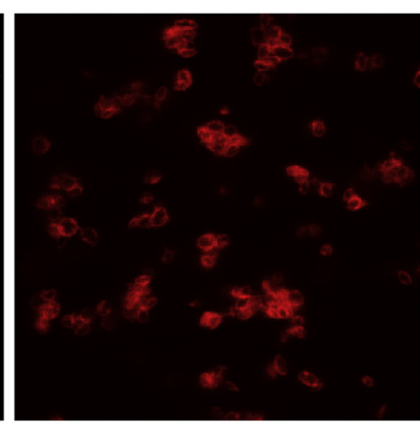

C

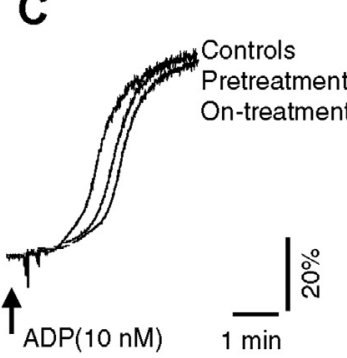

Merge
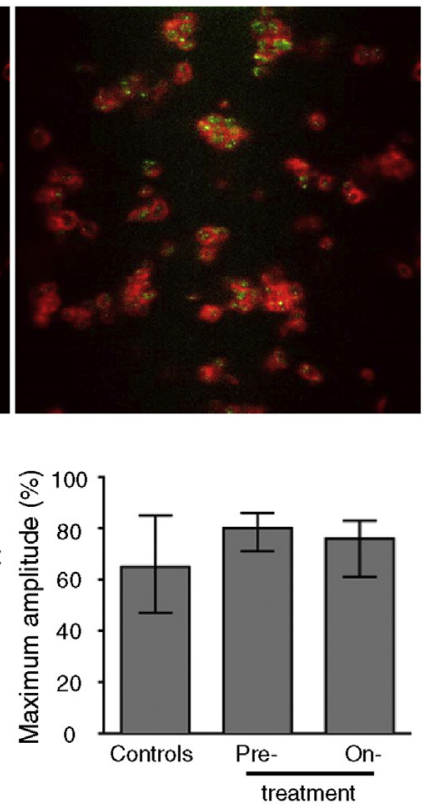
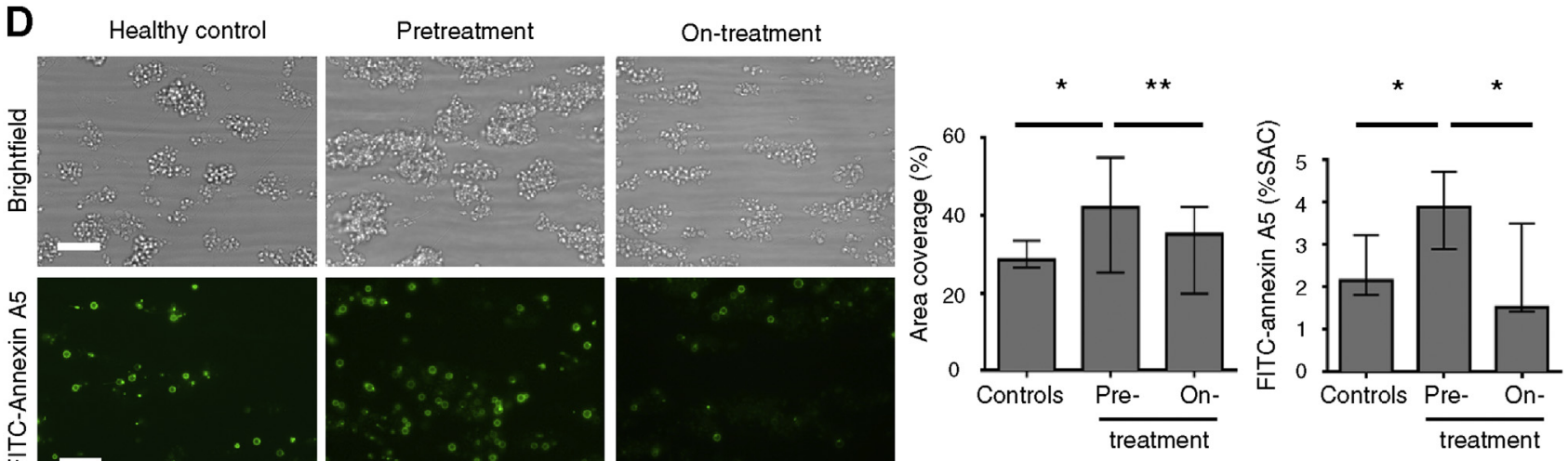

Fig. 3. Treatment with sunitinib inhibits collagen-induced platelet functioning in RCC patients. (A) Confocal microscopy of platelets from a patient after 2 weeks of sunitinib treatment (sunitinib = green). Platelet membranes were stained with anti-CD42b mAb (red). Note localisation of sunitinib inside the platelets (right image). Bar $=10 \mu \mathrm{m}$; (B-C) Blood was collected from healthy controls and RCC patients the day before and after 2 weeks on sunitinib treatment. Washed platelets $\left(250 \times 10^{9} / 1\right)$ were isolated, and aggregation was induced by $1 \mu \mathrm{g} / \mathrm{ml}$ collagen (B) or $10 \mathrm{nM}$ Me-S-ADP (C). Representative aggregation traces are shown. Arrow indicates addition of agonist. Histograms indicate maximal amplitude of aggregation $(\mathrm{n}=8)$. (D) Whole blood was perfused over a collagen surface at $1000 \mathrm{~s}^{-1}$ for $5 \mathrm{~min}$, followed by buffer perfusion supplemented with FITC-annexin A5. Microscopy images show representative brightfield and fluorescence images $($ Bar $=20 \mu \mathrm{m})$. Histograms indicate quantification of surface area coverage $($ SAC) by thrombi $(\mathrm{n}=8)$ and phosphatidylserine-exposing platelets $(\mathrm{n}=7)$. All histograms indicate medians \pm interquartile ranges, $* P<0.05$ and $* * P<0.01$. $\mathrm{DIC}=$ differential interference contrast $\mathrm{RCC}=$ renal cell cancer. (For interpretation of the references to colour in this figure legend, the reader is referred to the web version of this article.).

indeed showed that platelets treated with $10 \mu \mathrm{M}$ sunitinib, a dose resembling plasma concentrations in treated patients [18], take up sunitinib within minutes after exposure and sequester this fluorescent compound in granules.

Aggregation experiments of control platelets showed a selective inhibitory effect of sunitinib on collagen- and/ or ADP-induced aggregation, suggesting that sunitinib interferes with the signalling pathways activated by glycoprotein VI and/or $\mathrm{P}_{2} \mathrm{Y}_{12}$. The observed reduction of collagen-induced tyrosine phosphorylation of multiple proteins implies interference of sunitinib early in the signalling cascade used by the collagen receptor GPVI, e.g., with tyrosine kinases in the GPVI signalosome or with Syk as a central regulator of collagen-induced platelet activation. This is consistent with the multitarget nature of sunitinib as a broad-spectrum protein TKI $[2,19]$. Platelets contain several tyrosine kinases implicated in platelet functioning, mostly acting in the collagen-induced signalling pathway [4]. The finding 
that aggregation of the patients' platelets in response to ADP was not significantly inhibited by sunitinib treatment contrasts with the in vitro effect of sunitinib on control platelets; this parallels recent findings with ibrutinib [20,21]. The explanation for this distinction remains unknown.

Secretion of platelet-derived angiogenesis regulatory proteins is essential in tumour angiogenesis and tumour growth [7]. We observed that incubation of platelets with sunitinib resulted in a decrease of $\beta$-TG and PDGF secretion. Alpha granules are the main location of most angiogenesis regulatory proteins in platelets [22], suggesting that reduced secretion of $\beta-\mathrm{TG}$ and PDGF reflects reduced release of other angiogenesis regulatory proteins as well. Even though platelets contain both proangiogenic and antiangiogenic factors, their overall effect on tumour angiogenesis and growth is stimulatory [7]. Therefore, the inhibitory effect of sunitinib on platelet secretion suggests a new additional mechanism by which this drug can inhibit tumour angiogenesis and growth. This notion contributes to the idea that platelets are important actors in cancer development and should be taken into account, also when searching for bloodbased biomarkers [23].

The current data also show that, before starting sunitinib treatment, platelets from metastatic RCC patients display significantly enhanced collagen-induced thrombus formation and procoagulant activity in flow experiments, when compared to a control group of similar age and gender. These findings confirm the fact that cancer patients are at increased risk for thrombosis [24] and that metastatic cancer is associated with increased platelet reactivity [25]. Two weeks of sunitinib treatment significantly diminished thrombus formation and phosphatidylserine exposure to the healthy control level, normalising platelet functioning and reducing the risk for thrombosis.

Our results support other studies showing platelet inhibition by TKIs used for treatment of leukaemia. Dasatinib and imatinib, used for treatment of chronic myeloid leukaemia, have been demonstrated to inhibit platelet aggregation and thrombus formation in response to collagen and are associated with increased bleeding as well $[12,26]$. Ibrutinib, given to patients with chronic lymphocytic leukaemia, has also been linked to the occurrence of bleeding events and has been shown to inhibit collagen- and vWF-dependent platelet functions $[20,21,27]$. In contrast to imatinib, dasatinib and ibrutinib, sunitinib is a multitarget TKI affecting many protein tyrosine kinases [2,19]. Beside treatment of RCC and of imatinib-resistant gastrointestinal and pancreatic neuroendocrine tumours [2], the use of sunitinib for several other solid malignancies is currently being explored. Therefore, the present data are potentially relevant for large patient groups.

In summary, this study demonstrates that sunitinib is rapidly taken up by platelets and reduces collagen receptor-induced platelet aggregation and thrombus formation via inhibition of tyrosine phosphorylation and $\alpha$-granule secretion. In combination with its reducing effect on platelet count, this may contribute to the higher bleeding tendency observed in RCC patients treated with sunitinib. Therefore, clinicians should take ultimate care while using sunitinib in patients who previously experienced bleeding or use antiplatelet drugs. In addition, it is suggested to take platelet effects into account in the development of angiostatic compounds.

\section{Funding}

This research is financially supported by the Netherlands Organization for Scientific Research (NWO) under project number 017.008.143, granted to Siamack Sabrkhany, and by the Cardiovascular Centre Maastricht (Thrombosis Expertise Centre) to Johan Heemskerk and Marijke Kuijpers.

\section{Conflict of interest statement}

None declared.

\section{Appendix A. Supplementary materials}

Supplementary materials related to this article can be found at http://dx.doi.org/10.1016/j.ejca.2016.07.016.

\section{References}

[1] Gross S, Rahal R, Stransky N, Lengauer C, Hoeflich KP. Targeting cancer with kinase inhibitors. J Clin Invest 2015;125: 1780-9.

[2] Faivre S, Demetri G, Sargent W, Raymond E. Molecular basis for sunitinib efficacy and future clinical development. Nat Rev Drug Discov 2007;6:734-45.

[3] Je Y, Schutz FA, Choueiri TK. Risk of bleeding with vascular endothelial growth factor receptor tyrosine-kinase inhibitors sunitinib and sorafenib: a systematic review and meta-analysis of clinical trials. Lancet Oncol 2009;10:967-74.

[4] Versteeg HH, Heemskerk JW, Levi M, Reitsma PH. New fundamentals in hemostasis. Physiol Rev 2013;93:327-58.

[5] Munnix IC, Kuijpers MJ, Auger J, Thomassen CM, Panizzi P, van Zandvoort MA, et al. Segregation of platelet aggregatory and procoagulant microdomains in thrombus formation: regulation by transient integrin activation. Arterioscler Thromb Vasc Biol 2007:27:2484-90.

[6] Kuijpers MJ, Munnix IC, Cosemans JM, Vlijmen BV, Reutelingsperger CP, Egbrink MO, et al. Key role of platelet procoagulant activity in tissue factor- and collagen-dependent thrombus formation in arterioles and venules in vivo differential sensitivity to thrombin inhibition. Microcirculation 2008;15: 269-82.

[7] Sabrkhany S, Griffioen AW, Oude Egbrink MG. The role of blood platelets in tumor angiogenesis. Biochim Biophys Acta 2011;1815:189-96.

[8] Mattheij NJ, Gilio K, van Kruchten R, Jobe SM, Wieschhaus AJ, Chishti AH, et al. Dual mechanism of integrin $\alpha \operatorname{IIb} \beta 3$ closure in procoagulant platelets. J Biol Chem 2013;288:13325-36. 
[9] Li Z, Delaney MK, O’Brien KA, Du X. Signaling during platelet adhesion and activation. Arterioscler Thromb Vasc Biol 2010;30: 2341-9.

[10] Kitagawa D, Yokota K, Gouda M, Narumi Y, Ohmoto H, Nishiwaki E, et al. Activity-based kinase profiling of approved tyrosine kinase inhibitors. Genes Cells 2013;18:110-22.

[11] Byrd JC, Furman RR, Coutre SE, Flinn IW, Burger JA, Blum KA, et al. Targeting BTK with ibrutinib in relapsed chronic lymphocytic leukemia. N Engl J Med 2013;369: $32-42$.

[12] Quintas-Cardama A, Han X, Kantarjian H, Cortes J. Tyrosine kinase inhibitor-induced platelet dysfunction in patients with chronic myeloid leukemia. Blood 2009;114:261-3.

[13] Bair SM, Choueiri TK, Moslehi J. Cardiovascular complications associated with novel angiogenesis inhibitors: emerging evidence and evolving perspectives. Trends Cardiovasc Med 2013;23: 104-13.

[14] Choueiri TK, Schutz FA, Je Y, Rosenberg JE, Bellmunt J. Risk of arterial thromboembolic events with sunitinib and sorafenib: a systematic review and meta-analysis of clinical trials. J Clin Oncol 2010;28:2280-5.

[15] Nowak-Sliwinska P, Weiss A, van Beijnum JR, Wong TJ, Kilarski WW, Szewczyk G, et al. Photoactivation of lysosomally sequestered sunitinib after angiostatic treatment causes vascular occlusion and enhances tumor growth inhibition. Cell Death Dis 2015;6:e1641.

[16] Klement GL, Yip TT, Cassiola F, Kikuchi L, Cervi D, Podust V, et al. Platelets actively sequester angiogenesis regulators. Blood 2009; 113:2835-42.

[17] Verheul HM, Lolkema MP, Qian DZ, Hilkes YH, Liapi E, Akkerman JW, et al. Platelets take up the monoclonal antibody bevacizumab. Clin Cancer Res 2007;13:5341-7.
[18] Goodman VL, Rock EP, Dagher R, Ramchandani RP, Abraham S, Gobburu JV, et al. Approval summary: sunitinib for the treatment of imatinib refractory or intolerant gastrointestinal stromal tumors and advanced renal cell carcinoma. Clin Cancer Res 2007;13:1367-73.

[19] Karaman MW, Herrgard S, Treiber DK, Gallant P, Atteridge CE, Campbell BT, et al. A quantitative analysis of kinase inhibitor selectivity. Nat Biotechnol 2008;26:127-32.

[20] Kamel S, Horton L, Ysebaert L, Levade M, Burbury K, Tan S, et al. Ibrutinib inhibits collagen-mediated but not ADP-mediated platelet aggregation. Leukemia 2015;29:783-7.

[21] Rushworth SA, MacEwan DJ, Bowles KM. Ibrutinib in relapsed chronic lymphocytic leukemia. N Engl J Med 2013;369:1277-8.

[22] Blair P, Flaumenhaft R. Platelet alpha-granules: basic biology and clinical correlates. Blood Rev 2009;23:177-89.

[23] Sabrkhany S, Kuijpers MJE, Verheul HMW, Griffioen AW, oude Egbrink MGA. Platelets: an unexploited data source in biomarker research. Lancet Haematol 2015;2:e512-3.

[24] Buller HR, van Doormaal FF, van Sluis GL, Kamphuisen PW. Cancer and thrombosis: from molecular mechanisms to clinical presentations. J Thromb Haemost 2007;5(Suppl. 1):246-54.

[25] Cooke NM, Egan K, McFadden S, Grogan L, Breathnach OS, O'Leary J, et al. Increased platelet reactivity in patients with latestage metastatic cancer. Cancer Med 2013;2:564-70.

[26] Gratacap MP, Martin V, Valera MC, Allart S, Garcia C, Sie P, et al. The new tyrosine-kinase inhibitor and anticancer drug dasatinib reversibly affects platelet activation in vitro and in vivo. Blood 2009;114:1884-92.

[27] Levade M, David E, Garcia C, Laurent PA, Cadot S, Michallet AS, et al. Ibrutinib treatment affects collagen and von Willebrand factor-dependent platelet functions. Blood 2014;124: 3991-5. 